\title{
Investigating habitat value to inform contaminant remediation options: Approach is
}

\author{
Rebecca A. Efroymson ${ }^{\mathrm{a}, *}$, Mark J. Peterson ${ }^{\mathrm{a}}$, Christopher J. Welsh ${ }^{\mathrm{b}}$, \\ Daniel L. Druckenbrod ${ }^{\mathrm{a}, \mathrm{c}, 1}$, Michael G. Ryon ${ }^{\mathrm{a}}$, John G. Smith ${ }^{\mathrm{a}}$, William W. Hargrove ${ }^{\mathrm{a}, \mathrm{d}}$, \\ Neil R. Giffen ${ }^{\mathrm{a}}$, W. Kelly Roy ${ }^{\mathrm{a}}$, Harry D. Quarles ${ }^{\mathrm{a}}$ \\ ${ }^{a}$ Oak Ridge National Laboratory, Environmental Sciences Division, P.O. Box 3008, M.S. 6036, Oak Ridge, TN 37831, USA \\ ${ }^{\mathrm{b}}$ The Institute for Ecological Modeling, University of Tennessee, Knoxville, TN 37886, USA \\ ${ }^{\mathrm{c}}$ Longwood University, 201 High Street, Farmville, VA 23909, USA \\ ${ }^{\mathrm{d}}$ Eastern Forest Environmental Threat Assessment Center, USDA Forest Service Southern Research Station, \\ 200 WT Weaver Boulevard, Asheville, NC 28804-3454, USA
}

Received 3 November 2006; received in revised form 27 June 2007; accepted 18 July 2007

Available online 25 September 2007

\begin{abstract}
Habitat valuation methods are most often developed and used to prioritize candidate lands for conservation. In this study the intent of habitat valuation was to inform the decision-making process for remediation of chemical contaminants on specific lands or surface water bodies. Methods were developed to summarize dimensions of habitat value for six representative aquatic and terrestrial contaminated sites at the East Tennessee Technology Park (ETTP) on the US Department of Energy Oak Ridge Reservation in Oak Ridge, TN, USA. Several general valuation metrics were developed for three broad categories: site use by groups of organisms, site rarity, and use value added from spatial context. Examples of use value metrics are taxa richness, a direct measure of number of species that inhabit an area, complexity of habitat structure, an indirect measure of potential number of species that may use the area, and land use designation, a measure of the length of time that the area will be available for use. Measures of rarity included presence of rare species or communities. Examples of metrics for habitat use value added from spatial context included similarity or complementarity of neighboring habitat patches and presence of habitat corridors. More specific metrics were developed for groups of organisms in contaminated streams, ponds, and terrestrial ecosystems. For each of these metrics, cutoff values for high, medium, and low habitat value were suggested, based on available information on distributions of organisms and landscape features, as well as habitat use information. A companion paper describes the implementation of these habitat valuation metrics and scoring criteria in the remedial investigation for ETTP.
\end{abstract}

(C) 2007 Elsevier Ltd. All rights reserved.

Keywords: Habitat; Ecological valuation; Remediation; Contaminated site

\footnotetext{
The submitted manuscript has been authored by a contractor of the US Government under Contract DE-AC05-00OR22725. Accordingly, the US Government retains a nonexclusive, royalty-free license to publish or reproduce the published form of this contribution, or allow others to do so, for US Government purposes.

*Corresponding author. Tel.: + 1865574 7397; fax: + 18655768543 .

E-mail addresses: efroymsonra@ornl.gov (R.A. Efroymson), petersonmj@ornl.gov (M.J. Peterson), cwelsh@utk.edu (C.J. Welsh), druckenbroddl@longwood.edu (D.L. Druckenbrod), ryonmg@ornl.gov (M.G. Ryon), smithjg@ornl.gov (J.G. Smith), hargroveww@ornl.gov (W.W. Hargrove), giffennr1@ornl.gov (N.R. Giffen), roywk@ornl.gov (W.K. Roy), quarleshdiii@ornl.gov (H.D. Quarles).

${ }^{1}$ Formerly of Oak Ridge National Laboratory.
}

\section{Introduction}

The value of ecological resources may be determined from at least two perspectives: the value to humans and the value to ecological entities. The value of existing ecological resources to humans is often expressed as ecological or ecosystem services (Daily, 1997). These include ecological functions such as water purification, air purification, pollination, carbon sequestration, and primary production, as well as other services like recreation and aesthetic value (WRI, 2005). These ecosystem services have monetary value that is usually determined from market factors or 
surveys. Alternatively, land areas and water bodies may be valued based on the services that they provide to other ecological entities, such as wildlife and vegetation. These habitat services include food, shelter, breeding areas, and migratory pathways and other movement corridors. The value of habitat is generally expressed in descriptive rather than monetary terms. Habitat valuation processes are most often used to inform decisions about which lands to conserve (Rossi and Kuitunen, 1996). In this study the intent of habitat valuation is to inform the decision-making process related to remediation of chemical contaminants on specific lands or in surface water bodies.

Ecological risk assessments have been criticized for ignoring habitat or home range limitations of a site, as well as spatial patterns in habitat quality (Kapustka et al., 2001; Kapustka, 2003). Moreover, environmental scientists have argued that understanding and valuing ecological resources for decisions about future land use deserves equal consideration as ecological risk assessment of contamination (Burger et al., 2004). The motivation for this study was the belief that remedies for ecological risk should consider habitat value. For example, an industrialized area with low ecological habitat value and apparently high ecological risk (but low human health risk) might be of a lower priority for remediation than a more natural area with lower apparent ecological risk but high ecological habitat value. The argument that remediation might harm an ecological community more than toxicants in soils or waters (Whicker et al., 2004; Efroymson et al., 2004) may be supported or refuted with evidence concerning habitat value. Similarly, the recovery of ecological communities following remediation or natural attenuation of contaminants may be monitored through a habitat valuation process (Kapustka et al., 2004). Although natural resources valuation has been recommended for evaluating future land uses on US Department of Energy (DOE) uncontaminated lands (Burger et al., 2004), it has not previously been recommended for use in evaluating remedial decisions for chemical contaminants.

We conducted a broad study that was intended to summarize dimensions of habitat value in sufficient detail to aid remedial decisions for six representative aquatic and terrestrial contaminated sites at the ETTP on the US DOE Oak Ridge Reservation (ORR) in Oak Ridge, TN, USA (Efroymson et al., 2005). These results would supplement the findings of the baseline ecological risk assessment for the contaminant remedial investigation. This paper summarizes methods suitable for assessing habitat value for groups of organisms in contaminated streams, ponds, and terrestrial ecosystems. Many of the methods are specifically pertinent to the ORR, east Tennessee or the Appalachian Mountains. A companion paper presents a case study in which habitat value is assessed for the six contaminated sites (Efroymson et al., in press).

Some considerations related to habitat value and remediation are beyond the scope of this study, such as the duration and intensity of potential harm that may occur during a remedial action (Efroymson et al., 2004) and the desirable end state following remediation. Moreover, the question of how habitat value influences ecological exposure is not addressed.

\section{Theory}

\subsection{Existing methods for habitat valuation}

Numerous methods and metrics related to measuring ecological condition or valuing habitat are available for use. US Fish and Wildlife Service (USFWS) Habitat Evaluation Procedures (HEP) use habitat suitability factors to derive numerical indices of habitat suitability on a scale of $0.0-1.0$ based on the assumption that key environmental variables are related to habitat carrying capacity (USFWS, 1981). Some of the variables that determine wildlife habitat in HEP include: soil characteristics (particle size, moisture content, $\mathrm{pH}$, nutrient content, etc.), topography (slope, aspect), temperature, precipitation, vegetation characteristics (type, height, basal area, cover), distance to a specified land feature, and edge length per unit area (Hays et al., 1981). While chemical contamination is not typically one of the variables, it may be added. HEP is generally used to compare the relative value of two sites at the same point in time, or one site at two different points in time (USFWS, 1981).

Various methods have been developed to prioritize land areas for conservation. Margules and Usher (1981) found that five metrics were used in the majority of studies that they reviewed: diversity, rarity, naturalness, area, and threat of human interference. Early assessments did not include notions of connectivity and fragmentation from landscape ecology. More recently, Rossi and Kuitunen (1996) defined a habitat value index, based on species present, their threat (rarity) categories, and the likelihood of occurrence in specific land cover areas.

Several monitoring methods have been developed to characterize the status and trends of aspects of the environment. These include the US Environmental Protection Agency's (EPA's) Rapid Bioassessment Protocols (RBPs, Barbour et al., 1999) and their Environmental Monitoring and Assessment Program (USEPA, 2002). Indicators within these protocols may be useful measures of habitat value; for example, physicochemical parameters for habitat assessment in RBPs may be used to estimate habitat complexity, which may be related to species richness.

The Critical Ecosystem Assessment Model (CrEAM) is a USEPA Region 5, geographic information system (GIS)based method of determining "ecosystem ecological significance" based on ecological diversity, ecological sustainability, and rare species and land cover. Like the goals of this project, the emphasis is on ecological conditions rather than societal values such as flood damage mitigation or recreational value (White and Maurice, unpublished manuscript). Field measurements are not part of these methods. Measures of ecological diversity include 
patch size of undeveloped land, land cover diversity, temperature and precipitation maxima, and temporal continuity of land cover type. Sustainability metrics are based on landscape fragmentation (e.g., perimeter to area analysis, waterway impoundment) and stressor presence (e.g., Superfund site, air quality summary). Included among rarity metrics are land cover rarity, species rarity, rare species abundance, and rare species taxa abundance (White and Maurice, unpublished manuscript).

EPA Region 7 also has developed tools for identifying critical ecosystems. Ecological significance of land areas is determined based on patch areas that have vegetation similar to modeled historic vegetation, as well as areas with opportunity for conservation (Missouri Resource Assessment Partnership, 2004). Ecological threat, another component of critical ecosystem assessment, is based on land demand, agriculture, and toxic releases. Ecological risk is based on the integration of significance and threat. The third component score for determining critical terrestrial ecosystems is the ranking for "irreplaceability", which indicates the uniqueness of a given site for achieving specified conservation goals, and includes landscape-scale factors and species richness (Missouri Resource Assessment Partnership, 2004).

Kapustka et al. (2004) have modified a layers of habitat model developed by Short (1984) to provide an indication of biodiversity potential and ecological recovery. They have predicted wildlife species richness for locations surrounding a contaminated copper mine site, based on vertical and horizontal diversity of vegetation cover types.

Habitat Equivalency Analysis (HEA) is a method used to determine equivalent ecological service areas in Natural Resource Damage Assessment applications or other ecological restoration analyses. Habitat services are measured by a metric of a single factor or a metric that integrates multiple factors (Dunford et al., 2004). Resource Equivalency Analysis is a more specific type of HEA, in which the number of organisms lost can be estimated in damaged habitat areas and equated to area of replacement habitat (Allen et al., 2005).

The Nature Conservancy is currently working with the Tennessee Wildlife Resources Agency to coordinate development of the Tennessee Comprehensive Wildlife Conservation Strategy (Kirk and Bullington, 2005). Conservation priorities will include areas with "high biological value [high species diversity areas and high quality habitats], imperilment, and strategic opportunity," and methods of habitat valuation will reflect these factors.

In 1995 the Nature Conservancy identified sites on the ORR with clusters of important species or communities, placing special emphasis on species and elements designated as globally imperiled, rare, or uncommon in The Nature Conservancy and Natural Heritage Network ranking system (TNC, 1995). These sites also include the landscape features and ecological processes that were deemed important habitat for these species and communities. A biological significance ranking (BSR) was assigned to each site based on its conservation significance. Sites on the ORR were rated BSR-2 (very high significance), BSR-3 (high significance), and BSR-4 (moderate significance) (Fig. 1). The BSR-5 category (of general biodiversity interest) was not used in TNC (1995), although they noted that "forested land on ORR would fit in this or [a higher] category" (ORNL, 2002). Sites on the ORR were evaluated primarily based on existing data; therefore unsurveyed sites were not evaluated.

These and other habitat valuation methods have differences in terms of data requirements, time requirements, and management goals. Habitat-specific methods tend to be species-specific. Methodologies intended to measure the status and trend of ecological condition may not provide criteria for distinguishing between levels of good or poor habitat value. Some methods are not applicable to the several hectare scale at which risk managers make remedial decisions.

\subsubsection{Multimetric indices}

Multimetric indices are used in comparisons and estimates of the status and trends of ecosystems. Many of the methodologies described above (e.g., CrEAM) are indices (though we have emphasized the component variables in our discussion). An additional example is the Index of Biotic Integrity (Karr, 1981), which requires extensive training to administer. Multimetric indices have gained acceptance, particularly among aquatic toxicologists and aquatic ecologists, and are widely used in environmental monitoring and regulation (Bruins and Heberling, 2005; Shelton and Blocksom, 2004). The Clean Water Act language referring to "biological integrity" promotes the use of the indices. Indices often reflect managers' preference for a simple or reductionist approach to habitat evaluations (Diaz et al., 2004); a single number is arguably easier to use in decision making than a suite of numbers. This type of reductionism may be convincing if the relationship between the components and the whole is well understood (e.g., the relationship between vegetation structure and wildlife habitat and species richness in Kapustka et al., 2004). The growth of the use of indices is reflected in Diaz et al. (2004), who summarize 64 benthic habitat quality indices.

Habitat value is not easily expressed as a single, number useful for comparing relatively similar habitat areas (Bond et al., 1999), or, in the case of this valuation of candidate sites for contaminant remediation, very disparate lands and surface waters. Indices have several disadvantages for broadly valuing land areas or water bodies as habitat. First, if managers have not fully expressed their relative value for different aspects of habitat, then an index is not useful. Moreover, users of habitat valuation methods will probably have different weightings that they would like to apply to the various scores to support their needs for decision-making that cannot be reflected in a single generically weighted index. Particular metrics may only be indicative of habitat value in certain environments. Also, in this analysis many habitat value criteria are 


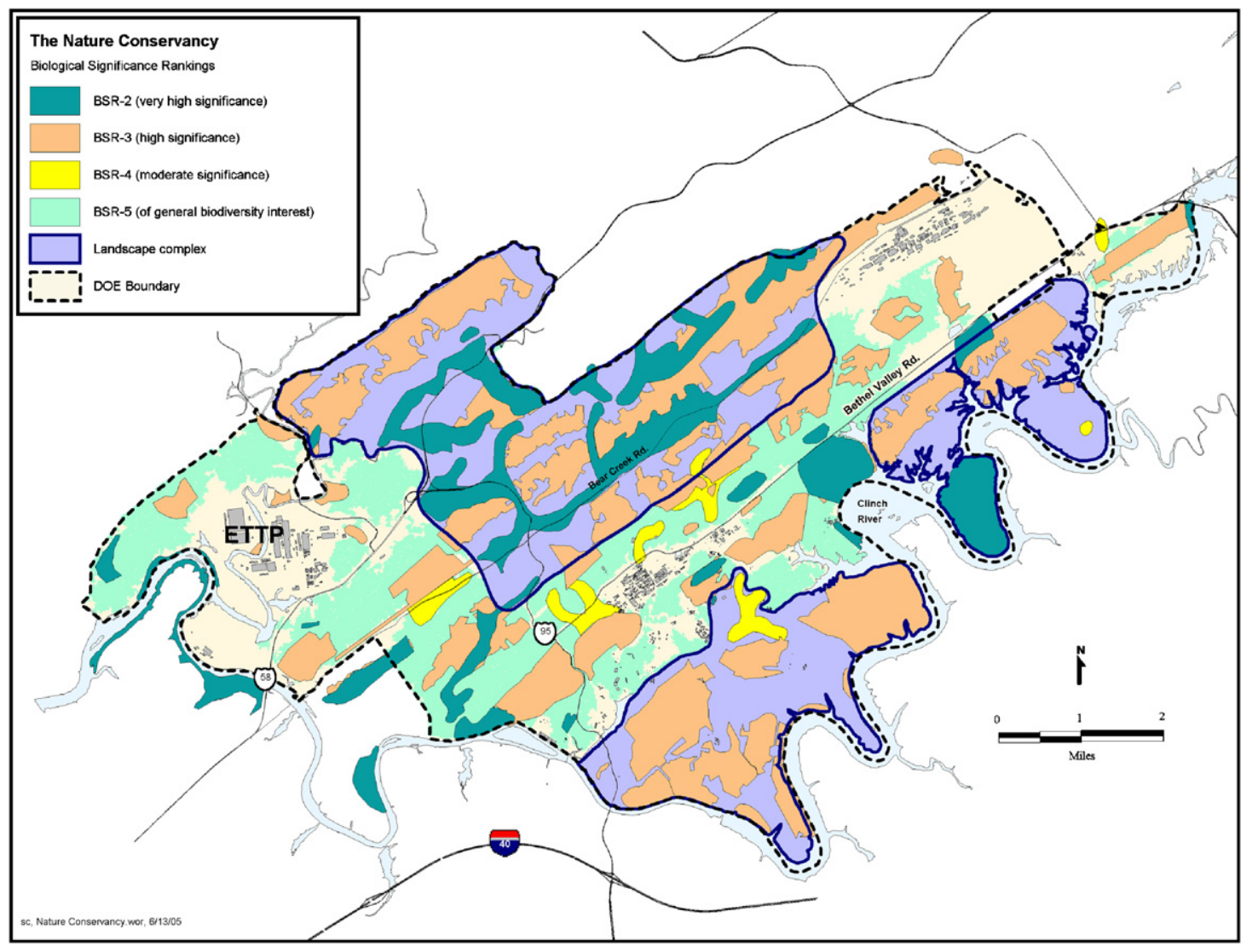

Fig. 1. The Nature Conservancy's Biological significance rankings for the Oak Ridge Reservation, Oak Ridge, TN (TNC, 1995). ETTP designates the location of the East Tennessee Technology Park. Color figure appears in PDF and HTML versions of manuscript downloadable from internet.

developed with respect to different spatial scales, depending on data availability and information from the literature. Some of Suter's (1993) criticisms of ecosystem health indices would also apply to an attempt to attribute a single number to the habitat value of each of the six sites at ETTP. Several of his arguments against indices include:

- Ambiguity: If an index is low, one cannot tell if it is because two components were very low, or several components were somewhat low.

- Arbitrariness of combining functions: An index may be very sensitive to the multiplicative, additive or other process used to calculate it.

- Arbitrariness of variance: The variance of an index does not have a clear relationship to any biological response.

- Unreality: Indices are not measures of real-world properties.

- Disconnection from testing: Indices cannot be tested in the laboratory or verified in the field.

\section{Approach}

\subsection{Agency participation}

During the planning meetings for the ecological risk assessment for ETTP, representatives of regulatory agen- cies expressed an interest in having more information on the relative habitat value of contaminated sites. This study was designed to address questions about habitat values at select sites at ETTP. Representatives of EPA, USFWS, and the Tennessee Department of Environment and Conservation (TDEC) participated in the discussions about the scope of this study and reviewed candidate metrics for valuation of habitat.

\subsection{General valuation metrics}

Several general categories of metrics were selected from the literature on habitat valuation, habitat evaluation, habitat suitability assessment, and conservation prioritization. These metrics were subsequently operationalized for streams, ponds, and terrestrial ecosystems on the ORR in Oak Ridge, TN. We assumed the following:

- that supply and demand guide the selection of habitat by organisms, just as they guide human economic behavior,

- that use of an area by a species for any purpose indicates demand for that type of environment (i.e., the speciesrealized niche in that area) and represents habitat $\mathrm{v}$ alue,

- that a rare vegetation community or rare aquatic landscape feature is in low supply and indicates high habitat value for species that require it, 
- that area and time are dimensions of habitat value,

- that spatial context of a site can provide added habitat value to the site,

- that performing numerous species-specific habitat evaluations would result in approximately the same range of habitat value scores as the more general methods selected here, and

- that a multimetric index would not provide as much or as useful information as individual scores for various habitat value metrics.

The general metrics for scoring habitat value are presented in Table 1.

\subsubsection{Site use value}

The core determinant of habitat value is use (for food and water resources, reproduction, and migration or other movement). Use is a multidimensional quantity that should include intensity, spatial extent, and temporal duration. Area is an important dimension of use value. For two similar areas, a larger habitat patch is generally more valuable as habitat than a smaller one, although edge distance is also an important habitat value factor for some taxa such as edge-associated birds. Similarly, a patch that will become a residential development in 10 years is less valuable than one that will be available for a longer period of time through conservation efforts. Therefore, we think of habitat use value as the product of use, area and time. However, the semiquantitative measures of use, the inexact areas, and the highly uncertain durations of habitat value prohibit us from performing this calculation. This product is consistent with calculations in HEA, whose output is typically service-acre-years.

A direct measure of use of a site by various populations is species diversity or taxa richness (Table 1). Moreover, properties of ecosystems are partly determined by biodiversity, i.e., the functional characteristics of species as well as the distribution and abundance of organisms through space and time (Hooper et al., 2005). An increasing number of ecologists view biodiversity as an insurance policy or buffer against major ecosystem functional change (Doherty

Table 1

Metrics for valuing habitat at six contaminated sites

\begin{tabular}{|c|c|c|}
\hline Type of value ${ }^{a}$ & Metric & Explanation \\
\hline \multirow[t]{8}{*}{ Site use value } & Taxa richness & Direct measure of number of species that inhabit area. \\
\hline & Number of sensitive species & $\begin{array}{l}\text { Subset of diversity and number of species that use area. Absence provides indication of level of } \\
\text { degradation of area. }\end{array}$ \\
\hline & $\begin{array}{l}\text { Complexity of habitat } \\
\text { structure }\end{array}$ & Indirect measure of potential number of species that may use area. \\
\hline & $\begin{array}{l}\text { Presence of special wildlife } \\
\text { habitat services }\end{array}$ & $\begin{array}{l}\text { Presence of bird rookeries, bat maternity roosts, male display areas, vernal pools, or other wildlife } \\
\text { breeding areas that indicate greater use and importance compared to similar areas without } \\
\text { features. }\end{array}$ \\
\hline & $\begin{array}{l}\text { Habitat suitability } \\
\text { relationship for broad taxa }\end{array}$ & $\begin{array}{l}\text { Relationships provide information on whether particular vegetation associations or other } \\
\text { environmental quality variables are highly suitable or not suitable for particular broad taxa. }\end{array}$ \\
\hline & $\begin{array}{l}\text { Number of invasive or } \\
\text { nonnative species }\end{array}$ & $\begin{array}{l}\text { Nonnative species decrease use by native species. Invasive species also decrease use by native } \\
\text { species, and footprint increases with time, if unchecked (therefore, area-weighted use value for } \\
\text { native species decreases with time). }\end{array}$ \\
\hline & Land cover designation & $\begin{array}{l}\text { If majority of land area paved or covered with buildings, habitat value low because of lack of } \\
\text { vegetation, minimal habitat structure, and fragmentation. }\end{array}$ \\
\hline & Land use designation & $\begin{array}{l}\text { If land use designated as industrial area, habitat use value may not continue for as long as it would } \\
\text { if area were conserved. }\end{array}$ \\
\hline
\end{tabular}

Site rarity $\quad$ Presence of rare species Current value of habitat high if rare species use it. State and federal listed and candidate species considered rare for this study.

Presence of rare community Rare community implies little redundancy or substitutability for habitat services, and potentially high demand for site.

Use value added from Presence of similar, adjacent Use value of habitat patch increases with area, because some species need minimal patch areas for spatial context habitat patch home ranges, territories, or viable populations. In addition, size of habitat patch correlated with diversity.

Presence of ecological Presence of migration and other movement corridors indicates that community of site in question corridor adds use value to surrounding habitat and that surrounding communities add use value to habitat on site.

Adjacency to complementary Arrangement of communities can add value to organisms that enjoy services of each (e.g., land or water

Adjacency to conservation Habitat value of site adjacent to reserve would probably persist longer than habitat value of other land use area sites.

\footnotetext{
The major components of value are use, rarity, and use value added from spatial context.

a"Use" is habitat use by groups of organisms, "rarity" is scarcity of population or habitat, "use from spatial context" is value added to habitat value based on location.
} 
et al., 2000). However, it is notable that species richness scales with area (Storch et al., 2005).

Indirect measures of use by a large number of species are presence of sensitive species, presence of complex habitat structure, and broad habitat suitability relationships (Table 1). The presence of sensitive (sometimes called "intolerant") faunal species implies that physical, chemical, or biological disturbances are not very intensive or extensive, that habitat for a larger, sensitive group of taxa is present, and that species richness in general is probably high.

Biodiversity has been closely associated with habitat structural complexity by many researchers (Crowder and Cooper, 1982; Downes et al., 1998; Benton et al., 2003; Johnson et al., 2003). For example, the diversity of prey of bluegill sunfish (Lepomis macrochirus) was lower at low macrophyte density than at intermediate or high macrophyte density (Crowder and Cooper, 1982), though very high macrophyte density can lead to hypoxia (Miranda and Hodges, 2000). Some researchers argue that few empirical studies show associations between habitat conditions and biodiversity (Doherty et al., 2000), and quantitative methods for assessing habitat structural complexity are much more common in streams (Barbour et al., 1999) than in terrestrial systems (Newsome and Catling, 1979) or ponds.

The presence and spatial extent of invasive species are important determinants of habitat value (Burger et al., 2004). We assume that nonnative species take niches that would be occupied by native species, and therefore the diversity of nonnatives is an indicator of reduced use value by native species (Table 1). The susceptibility to invasion by exotic species is strongly influenced by species composition, as well as disturbance regime. Roads and powerline right-of-ways are viewed as corridors for exotic species.

Invasive plant species may be assumed to indicate lower habitat quality than just nonnatives, because invasive species have the potential to increase their abundances so rapidly that they can dominate the landscape. In contrast, it is more difficult to identify invasive fish species as a subset of nonnative fish species; nonnative fish can rarely increase their populations to dominate a system, unless the system is severely impacted or artificially constrained. However, species such as grass carp (Ctenopharyngodon idella) exert a large effect on pond habitat structure and composition without becoming the dominant species.

\subsubsection{Rarity}

Another determinant of habitat value is rarity, or the lack of substitutes (Table 1). A rare vegetation association is more valuable than an association with more substitutes, especially if organisms are closely adapted to that vegetation association. Rossi and Kuitunen (1996) have argued that the presence of rare species also makes a biotic community more unique and valuable. An important dimension of rarity is the region or land area-i.e., rare with respect to what particular spatial area?
Rare plant or bird species are often indicative of rare vegetation associations (SAMAB, 1996b). In general, older successional communities are rarer than early successional ones, especially within forest cover zones. However, this assertion depends on the spatial scale of concern and surrounding land cover. The presence of legacy trees can be associated with high wildlife diversity (Mazurek and Zielinski, 2004).

It is notable if the occurrence of landscape features (such as stream density or water cover) is much higher than a regional average. Then the density of that land cover type may be viewed as rare for the region. This type of measure is particularly important in the context of remedial actions that can alter the ratio of water body area to land area.

Wetlands communities generally have high societal value because of their decline nationally. In the period between 1986 and 1997, forested wetlands displayed the greatest areal decline of all wetland types, with a loss of 1.2 million acres, a $2.4 \%$ change. Freshwater emergent wetlands experienced a greater percentage decline, a $4.6 \%$ change, or 1 million acres, during the 11-year period (Dahl, 2000).

\subsubsection{Use value added from spatial context}

In addition to habitat use value that is easily measured, additional use value of a site may derive from its spatial context (Table 1). Ponds and streams serve as sources of drinking water for terrestrial organisms. Semlitsch and Bodie (2003) note that "biological interdependence between aquatic and terrestrial habitats is essential for the persistence of populations". Wetlands may increase the habitat value of adjacent lands and surface water bodies by removing toxicants entering aquatic ecosystems, reducing sediment loads, transforming nutrients, and serving as aquatic habitat (e.g., breeding habitat for amphibians) (King et al., 2000; Rosensteel and Awl, 1995). Forests and grasslands may serve as habitat for amphibians and reptiles that reproduce in wetlands or ditches (Semlitsch and Bodie, 2003). Forests may provide maternity roost sites for bats that forage above adjacent ponds.

The connectivity of habitat is often just as important as soil or vegetation type in determining if habitat for a particular wide-ranging species is adequate (Turner et al., 2001). For example, the presence of a vegetation association on a particular land area or a pond may create habitat corridors that improve the habitat quality or suitability of adjacent land areas or water bodies (Rosenberg et al., 1997; Hargrove et al., 2005, Table 1). Similarly, vegetated areas that provide cover for mammals and birds traveling through industrial land use areas would have high habitat value. The absence of the same riparian or other vegetation communities might be a measure of fragmentation of wildlife habitats, i.e., loss of area of the original habitats, reduction in habitat patch sizes, and increasing isolation of habitat patches. Fish require a waterway, flooded weir or fish ladder to move. Aquatic ecosystems are at least 
partially fragmented if weirs are present. Typically, fragmentation results in a decline of those species that avoid or will not move across unsuitable ecosystems, though species that thrive in ecotones (e.g., forest edges) may become more abundant (Andren, 1994).

Adjacency to a conservation land use area implies that habitat value will endure or may improve to the level of habitat quality in the conserved area (Table 1). Ostendorp (2004) provides an example as he includes the proportion of strictly enforced, conservation shore areas in determining his Quality Elements of an Integrated Lakeshore Quality Assessment.

\subsubsection{Metrics not selected}

A few measures of habitat value that are often associated with conservation actions are inappropriate here. For example, representativeness is often viewed as a criterion for reserve selection (Margules and Usher, 1981), which means that: (1) lands representing communities that are more common often get conserved first and (2) examples of all communities should eventually be conserved. In this study, rarity is viewed as a major component of value, which contrasts with the first meaning of representativeness described above. Similarly, conservation assessments often consider the risk of development among their habitat valuation metrics (Rossi and Kuitunen, 1996; Tans, 1974), because lands that are not threatened by development will retain their habitat value without formal conservation. In this study land use and the associated management practices are indicators of the duration of existing habitat value and provide information about the limits of succession (e.g., mowed areas in industrial parks or along powerline right-of-ways), but risk of development is not used as a measure of habitat value. Moreover, ecological fragility is sometimes considered a criterion for conserving land (Margules and Usher, 1981), but we do not believe that fragility indicates habitat value, unless it is related to rarity, and measures of rarity are already included in the analysis.

Several additional characteristics were considered but not selected as measures of habitat value. These include abundance, disturbance, replaceability, and area. Abundance could be used as a measure of habitat value but would have to be implemented carefully and perhaps arbitrarily. Many generalist species such as white-tailed deer, raccoons, and Canada geese are overabundant (Borenstein, 2005), and their numbers do not correlate well with habitat suitability for a variety of species of mammals and birds. McDonough and Hickman (1999) assert that the dominance of the fish community by one species is indicative of disturbance or degraded conditions. In addition, relative abundance of a species does not always correlate with ecosystem importance of a species, because rare species such as keystone predators can significantly influence energy and material flows (Hooper et al., 2005). The importance of various physical disturbances and to what extent the term "disturbance" represents physical or biological exposure versus biological effect are uncertain.

We also considered replaceability as a metric for the habitat valuation. Communities that cannot easily be replaced or reproduced are scored more highly than others in many valuation criteria supporting conservation decisions (Margules and Usher, 1981). This captures the fact that a mowed lawn or a concrete-lined stream may have substitutes elsewhere. However, replaceability is really a combination of the uncertain quantity of disturbance and rarity, which is the basis for multiple metrics of habitat value (Table 1). Moreover, Margules and Usher (1981) argue that the value of communities developed on artificial sites can only be determined if the course of ecological succession is accurately predicted. Karr et al. (1986) have asserted that the presence of altered habitat structure is one of the major stressors of aquatic systems, but we believe that this is accounted for directly in the habitat complexity measure and spatial context measures of use value, such as the presence or strength of ecological corridors and land cover adjacency, and indirectly in measures of diversity.

Clearly, area would be a pertinent measure of habitat value for sites within a single ecosystem. A larger, contiguous habitat patch is generally more valuable to any species than a smaller one. For example, rates of species loss are dependent on land or water body area (Margules and Usher, 1981). However, such a comparison cannot be made across ecosystem types (e.g., a small, ephemeral ditch may be highly valuable for amphibians). Area is not conducive to a particular valuation score unless it is linked to specific species and critical patch sizes for individuals (e.g., territory or home range size) or viable populations (Carlsen et al., 2004). For example, many species at higher trophic levels require large habitat areas (MacDonald, 2003).

\subsection{General criteria for scoring}

Measures of habitat value (specified below) were scored according to three levels of habitat quality: high, medium and low. Most supporting datasets allowed us to develop definitions of three categories of value, but we do not believe that more categories were justified. As Margules and Usher (1981) note, "Arbitrary definitions and value judgments do not lend themselves to quantification, yet quantification is essential for true comparisons to be made". Therefore, we chose as few categories as we believed would be useful for decision makers. When scores were highly uncertain, we provided a range of two levels (e.g., medium to high). Total habitat value indices were not calculated for each site for the reasons stated above.

For future scenarios, we did not have the data to support particular scores for various metrics. Recovery of ecosystem diversity, for example, does not automatically result in recovery of rare, native fauna (Stewart et al., 2005). 
Therefore, results of the habitat valuation for future scenarios were presented in a qualitative manner.

\subsection{Specific valuation criteria for various ecosystems}

The operationalization of measures of habitat value for various ecosystems was guided by: (1) data availability and (2) ease of development of criteria for high, medium, and low habitat value, based on descriptions or statistics from the literature or other reasonable definitions. High habitat value was unusually high, compared to typical value for the region of interest. Low value was unusually low. Medium habitat value was typical habitat value. Consistency in measurement was an additional criterion for selection of metrics. For example, taxa richness metrics for benthic invertebrates on the ORR tend to be more consistent than indices that combine richness and abundance.

If regional species abundance data were available (e.g., for the metric fish taxa abundance), we chose 25th and 75th percentiles as thresholds for high and medium, and medium and low habitat value designations. If data on pristine or reference conditions were available, percentile cutoffs were adjusted downward (e.g., number of sensitive benthic invertebrate species in streams in Table 2). Other metrics and scoring criteria were adopted from existing biotic indices (e.g., EPA Rapid Bioassessment Protocols). Some scoring criteria were based on thresholds for what is atypical for the region. For example, because $69.9 \%$ of the Southern Appalachian riparian zone is forested (SAMAB, 1996a), we set high habitat value for this zone as greater than $80 \%$ forested and low habitat value as less than $60 \%$ forested (Table 2). Similarly, because less than $40 \%$ of the Ridge and Valley riparian zone is forested (SAMAB, 1996a), we set high habitat value for this region at greater than $40 \%$ forested and low habitat value as less than $30 \%$ forested (Table 2). Habitat corridors were determined using the model described in Hargrove et al. (2005), and the presence of a corridor was determined to signify high habitat use value added from spatial context, and the absence of a corridor was determined to signify low habitat value.

Some measures were developed more arbitrarily - for example, qualitative characteristics assigned to the high, medium, and low categories based on the possible range of land cover occurrence data from the Southern Appalachian Man in the Biosphere program. Cutoffs for high, medium and low habitat value for abundance of sensitive and rare species were estimated by authors with the appropriate expertise. Also, we determined that the presence of invasive species lowers habitat value relative to the presence of noninvasive, nonnative species, which lowers habitat value relative to the absence of nonnatives. And we considered late successional areas (old growth forests) to be rarer than early successional areas.

Site descriptions provided additional information relevant to habitat value. Total site areas and proportion of sites taken up by different ecosystem types were included.
Although we did not opt to use disturbance as an independent measure for valuing habitat, we decided to include descriptions of actual disturbances or management practices as part of the site descriptions: presence of weir, absence of riparian zone, presence of concrete liner, substantial nutrient influx, presence of chemical contamination, pine beetle damage, erosion, plantation land cover, presence of burial ground, mowing, presence of roads, presence of buildings, and presence of scrap metal. Some of these disturbances were included in the analysis of habitat complexity, land cover, and ecological corridors.

Our analysis estimated habitat value in several spatial contexts: (1) the ORR, (2) the region around the ORR that is defined by areas that have been sampled previously as reference areas, (3) Roane County, TN (the county in which the ETTP portion of the ORR is located), (4) the Ridge and Valley physiographic province or ecoregion of the United States, or (5) the Southern Appalachian region that is the subject of the Southern Appalachian Man and the Biosphere Program (SAMAB, 2005). The SAMAB assessment area includes the Northern Piedmont, Southeastern Plains, Blue Ridge, Ridge and Valley, Southwestern Appalachians (including Cumberland Plateau), Central Appalachians, and Interior Plateau (SAMAB, 1996a, b; Omernik, 1995).

Specific criteria for scoring streams (Table 2), ponds (Table 3), and terrestrial lands (Table 4) were developed from the broad metrics in Table 1. Study sites are described in the companion manuscript (Efroymson et al., in press).

All metrics of habitat value and their regional contexts were dependent on available data (Table 2). Statistical data related to regional fish abundance are more prevalent than data on benthic invertebrate abundance and much more prevalent than analogous information for plants. Dissolved oxygen concentration was a habitat suitability variable that was available for all streams and ponds. This quantity is related to abundance and production of fish and invertebrates and is presumably related to diversity (Table 2).

While the ecology of the ORR has been studied extensively, we were unable to derive habitat value metrics based on vegetation community diversity. Vegetation cover type was used as a substitute. Scoring criteria for sensitive plants were not developed because no broad taxa are comparable to EPT taxa [Ephemeroptera (mayflies), Plecoptera (stoneflies), and Trichoptera (caddisflies) used to assess stream quality] for showing sensitivity to physical disturbance and soil quality. ${ }^{2}$ An exception might be spring ephemeral wildflowers in forests, but even these are often observed adjacent to roads. Burger et al. (2004) found that information on invasive species is not typically available for most DOE sites.

No metrics were developed for habitat value for mammals because of lack of data and the fact that most

\footnotetext{
${ }^{2}$ Some plant biologists argue that rarity indicates sensitivity in the plant kingdom.
} 
Table 2

Habitat value metrics and scoring criteria for streams

\begin{tabular}{|c|c|c|c|}
\hline Metric & High habitat value & Medium habitat value & Low habitat value \\
\hline Taxa richness - fish & $\begin{array}{l}>75 \% \text { (i.e., }>15 \text { species) of } 21 \text { possible } \\
\text { species occurrences in Clinch River } \\
\text { drainage }^{\text {a }}\end{array}$ & $\begin{array}{l}\text { Between } 25 \% \text { and } 75 \% \text { (i.e., 6-15) } \\
\text { species in Clinch River drainage }\end{array}$ & $\begin{array}{l}>25 \% \text { (i.e., }<6 \text { species) of } 21 \text { possible } \\
\text { species occurrences in Clinch River } \\
\text { drainage }\end{array}$ \\
\hline
\end{tabular}

Taxa richness-benthic invertebrates

Taxa richness - waterbird ${ }^{\mathrm{c}}$

Number of sensitive fish species $^{\mathrm{d}}$

Number of sensitive benthic invertebrate species ${ }^{\mathrm{e}}$

Shallow, slow-flowing areas for amphibian reproduction

Presence of waterbird rookery $^{\mathrm{f}}$

Presence of nonnative or invasive species ${ }^{\mathrm{g}}$

Complexity of habitat structure

\section{Abundance of rare species-fish}

Presence of rare speciesbenthic invertebrates

Presence of rare community—wetlands

Presence of movement corridor-fish

Presence of movement corridor-benthic invertebrates

Presence of movement corridor-avian piscivores

Stream density relative to Roane County, Lower Clinch River, and Southern Appalachian regional averages
Mean taxa richness equivalent to that found at reference streams around and within the $\mathrm{ORR}^{\mathrm{b}}$ (Smith et al., 2005), i.e., $\geqslant 25$ th percentile of reference distribution (Gerritsen, 1995) $\geqslant 28$

$>75 \%$ (i.e., $>11$ ) of 15 waterbird species observed at ETTP during 10 months of surveys in 2004

$>1$ sensitive species present (Northern hogsucker, banded sculpin, logperch, Stripetail darter, snubnose darter)

Mean EPT taxa richness equivalent to that found at reference streams around and within ORR (Smith et al., 2005), i.e., $\geqslant 25$ th percentile of reference distribution (i.e., $\geqslant 11$ )

Extensive shallow areas present

Rookery present

Mean taxa richness 12.5-24th percentile of reference distribution for streams around and within the ORR (Smith et al., 2005) i.e., 23-27

Between $25 \%$ and $75 \%$ (i.e., 4 to 11 ) of 15 bird species observed at ETTP during 10 months of surveys in 2004

1 sensitive species present

Mean EPT taxa richness of 12.5-24th percentile of reference distribution for streams around and within ORR (Smith et al., 2005) (i.e., 9-10)

Few shallow areas present

Mean taxa richness of $<12.5$ percentile of the reference distribution of streams around and within the ORR (Smith et al., 2005) i.e., $\leqslant 22$

$<25 \%$ (i.e., $<4$ ) of 15 waterbird species observed at ETTP during 10 months of surveys in 2004

No sensitive fish species present

Mean EPT taxa richness of $<12.5$ percentile of reference distribution of streams around and within ORR (Smith et al., 2005) (i.e., $\leqslant 8$ )

Shallow areas absent

Rookery absent

Nonnative, noninvasive species present

Invasive species present

More than 1 individual (flame chub, spotfin chub, Tennessee dace)

Rare mussels present (applicable to large streams only)

Presence of floodplain pool, boggy forested wetlands, or streamhead seepage swamps (rare communities according to TNC, 1995)

Easily accessible to upstream and downstream sources of fish for colonization; wide range of taxa that include species that are not strong swimmers indicates that weirs are easily accessible at high flows and high water levels

Upstream, downstream, and nearby stream sources of invertebrates for colonization; if weir is present, it is sometimes crossed

Additional water bodies within territory of herons, kingfishers, and ospreys and rookeries or nests near those water bodies

Stream density above $15 \mathrm{ft}$ per acre
Score of 33-131 for 10 physical and vegetation habitat parameters in EPA Rapid Bioassessment Protocols

(Barbour et al., 1999)

One individual

Score of $<33$ for physical and vegetation 10 habitat parameters in EPA Rapid Bioassessment Protocols (Barbour et al., 1999)

No individuals

Rare mussels absent (applicable to large streams only)

NA

Easily accessible to upstream or colonization

One or two sources of invertebrates for colonization from upstream, downstream, or adjacent stream sources

NA acre downstream sources of fish for

Stream density between 10 and $15 \mathrm{ft}$ per
Absence of floodplain pool, boggy forested wetlands, or streamhead seepage swamps (rare communities according to TNC, 1995)

Not easily accessible to upstream and downstream sources of fish for colonization

Poor upstream or downstream sources of invertebrates for colonization; weir is seldom crossed; no stream nearby

No additional water bodies within territory of herons, kingfishers, osprey, etc.

Stream density below $10 \mathrm{ft}$ per acre 
Table 2 (continued)

\begin{tabular}{|c|c|c|c|}
\hline Metric & High habitat value & Medium habitat value & Low habitat value \\
\hline $\begin{array}{l}\text { Riparian wetland coverage, } \\
\text { relative to Southern } \\
\text { Appalachian regional }^{j} \\
\text { average }^{j}\end{array}$ & $\begin{array}{l}>2 \% \text { of stream riparian zone is } \\
\text { wetlands } \mathrm{s}^{\mathrm{k}}\end{array}$ & $\begin{array}{l}0.5-2 \% \text { of stream riparian zone is } \\
\text { wetlands }\end{array}$ & $\begin{array}{l}<0.5 \% \text { of stream riparian zone is } \\
\text { wetlands }\end{array}$ \\
\hline $\begin{array}{l}\text { Forested riparian coverage, } \\
\text { relative to Southern } \\
\text { Appalachian regional } \\
\text { coverage }\end{array}$ & $\begin{array}{l}>80 \% \text { of stream riparian zone is } \\
\text { forested }^{1}\end{array}$ & $\begin{array}{l}60-80 \% \text { of stream riparian zone is } \\
\text { forested }\end{array}$ & $\begin{array}{l}<60 \% \text { of stream riparian zone is } \\
\text { forested }\end{array}$ \\
\hline $\begin{array}{l}\text { Forested riparian coverage, } \\
\text { relative to Ridge and Valley } \\
\text { regional coverage }\end{array}$ & $\begin{array}{l}>40 \% \text { of stream riparian zone is } \\
\text { forested }^{\mathrm{m}}\end{array}$ & $\begin{array}{l}30-40 \% \text { of stream riparian zone is } \\
\text { forested }\end{array}$ & $\begin{array}{l}<30 \% \text { of stream riparian zone is } \\
\text { forested }\end{array}$ \\
\hline Adjacent amphibian habitat & $\begin{array}{l}\text { Amphibian foraging, refuge or } \\
\text { overwintering habitat zone } \mathrm{e}^{\mathrm{n}} \text { to a } \\
\text { distance of at least } 159-290 \mathrm{~m} \\
\text { (Semlitsch and Bodie, 2003) } \\
\text { surrounding }>75 \% \text { of wetland area at } \\
\text { site }\end{array}$ & $\begin{array}{l}\text { Amphibian foraging, refuge or } \\
\text { overwintering habitat zone to a distance } \\
\text { of at least } 159-290 \mathrm{~m} \text { (Semlitsch and } \\
\text { Bodie, 2003) surrounding } 25 \%-75 \% \text { of } \\
\text { wetland areas at site or to a distance of } \\
\text { at least } 80 \mathrm{~m} \text { surrounding at least } 75 \% \\
\text { of wetland areas at site }\end{array}$ & $\begin{array}{l}\text { Amphibian foraging, refuge or } \\
\text { overwintering habitat zone to a distance } \\
\text { of at least } 159-290 \mathrm{~m} \text { (Semlitsch and } \\
\text { Bodie, 2003) surrounding }<25 \% \text { of } \\
\text { wetland area at site or to a distance of } \\
\text { less than } 80 \mathrm{~m} \text { surrounding }<50 \% \text { of } \\
\text { wetland area at site }\end{array}$ \\
\hline Adjacent reptile habitat & $\begin{array}{l}\text { Reptile upland habitat zone for nesting, } \\
\text { aestivating, feeding, hibernating, and } \\
\text { basking to a distance of at least } \\
127-289 \mathrm{~m} \text { (Semlitsch and Bodie, 2003) } \\
\text { surrounding }>75 \% \text { of wetland area at } \\
\text { site }\end{array}$ & $\begin{array}{l}\text { Reptile upland habitat zone for nesting, } \\
\text { aestivating, feeding, hibernating, and } \\
\text { basking to a distance of at least } \\
127-289 \mathrm{~m} \text { (Semlitsch and Bodie, } 2003 \text { ) } \\
\text { surrounding } 25 \%-75 \% \text { of wetland areas } \\
\text { at site or to a distance of at least } 80 \mathrm{~m} \\
\text { surrounding at least } 75 \% \text { of wetland } \\
\text { areas at site }\end{array}$ & $\begin{array}{l}\text { Reptile upland habitat zone for nesting, } \\
\text { aestivating, feeding, hibernating, and } \\
\text { basking to a distance of at least } \\
127-289 \mathrm{~m} \text { (Semlitsch and Bodie, } 2003 \text { ) } \\
\text { surrounding }<25 \% \text { of wetland area at } \\
\text { site or to a distance of less than } 80 \mathrm{~m} \\
\text { surrounding }<50 \% \text { of wetland area at } \\
\text { site }\end{array}$ \\
\hline
\end{tabular}

ETTP: East Tennessee Technology Park;

ORR: Oak Ridge Reservation;

EPT: Ephemeroptera, Plecoptera, and Trichoptera;

NA: not applicable.

${ }^{\text {a }}$ Based on distributional and habitat use information in Etnier and Starnes (1993) specific to streams in the Clinch River drainage within the Ridge and Valley Province, TN.

${ }^{\mathrm{b}}$ Reference streams include Pinhook Branch, Gum Hollow Branch (2 locations), Mill Branch, First Creek, Fifth Creek, White Oak Creek headwaters, University of Tennessee Farm Creek, and Mitchell Branch headwaters. Eight of the reference sites were located in second growth forests that have been minimally disturbed for about 50 years.

${ }^{\mathrm{c}}$ We have no regional reference, ecoregional, or Appalachian data for waterbirds. Also, waterbird surveys are less quantitative than other types of surveys because different ecosystem types have different visibility. Clearly, expected diversity at streams should be different from that at ponds, but we have no means to determine how, nor can we relate expected diversity to shore length.

${ }^{\mathrm{d}} \mathrm{T} \& \mathrm{E}$ species have rare and spotty distributions in region, and we believe that abundance of these individuals is a better measure of rarity than number of rare species. Sampling effort is an important determinant of the number of rare individuals identified. For the subject and reference streams in Efroymson et al. (in press), sampling is rigorous and has been undertaken for two decades. The valuation metric is a simple, relative one, based on experience.

${ }^{\text {e}}$ Sampling effort is an important determinant of the number of sensitive species identified. For the subject and reference streams in Efroymson et al. (in press), sampling is rigorous and has been undertaken for two decades. The valuation metric is a simple, relative one, based on experience.

${ }^{\mathrm{f}}$ Rookeries would not be expected at small streams.

${ }^{\mathrm{g}}$ Nonnative fish species cannot be determined, because regional status of North American fish species is uncertain, and the stream is too small for Asian nonnatives such as common carp and grass carp. The stream is also too small for nonnative mussels.

${ }^{\mathrm{h}}$ Minimum score for protection of stream habitat based on habitat assessments for several reference streams in Tennessee ecoregion 67f-Southern Limestone/Dolomite Valleys and Low Rolling Hills region (Arnwine and Denton, 2001).

${ }^{\mathrm{i}}$ Mean density of stream and river channels is $12 \mathrm{ft}$ per acre in the Southern Appalachians, $11.02 \mathrm{ft}$ per acre in Roane County, and $15 \mathrm{ft}$ per acre in Lower Clinch River watershed (SAMAB, 1996a).

${ }^{\mathrm{j}}$ Because this average is based on a 30-m buffer, our range has a higher midpoint, allowing for smaller wetlands at lower resolution.

${ }^{\mathrm{k}}$ Riparian zone wetlands average $0.7 \%$ of total riparian area for Southern Appalachian Assessment area (SAMAB, 1996a).

${ }^{1} 69.9 \%$ of the Southern Appalachian riparian zone is forested (SAMAB, 1996a).

${ }^{\mathrm{m}}$ Less than $40 \%$ of the Ridge and Valley riparian zone is forested (SAMAB, 1996a).

${ }^{\mathrm{n}}$ Consisting of leaf litter, coarse woody debris, boulders, small mammal burrows, cracks in rocks, spring seeps and rocky pools.

mammals on the ORR are generalists. Habitat metrics are not assumed to represent valuation factors for all species. For example, a recent article described the habitat value of powerline rights-of-way that were managed for dense scrub, compared to the value for those mowed or managed with pesticides (Russell et al., 2005). This type of habitat value (and ecological service value) was not captured in our study. 
Table 3

Habitat value metrics and scoring criteria for ponds

\begin{tabular}{|c|c|c|c|}
\hline Metrics & High habitat value & Medium habitat value & Low habitat value \\
\hline Taxa richness - fish & $\begin{array}{l}>75 \% \text { (i.e., }>27 \text { species) of } \\
\text { possible species occurrences in } \\
\text { Clinch River drainage }^{\mathrm{a}}\end{array}$ & $\begin{array}{l}\text { Between } 25 \% \text { and } 75 \% \text { (i.e., } 10-26 \\
\text { species) of possible species } \\
\text { occurrences in Clinch River } \\
\text { drainage }\end{array}$ & $\begin{array}{l}>25 \% \text { (i.e., }<10 \text { species) of } \\
\text { possible species occurrences in } \\
\text { Clinch River drainage }\end{array}$ \\
\hline $\begin{array}{l}\text { Taxa richness-Lepomid } \\
\text { sunfish species }{ }^{b}\end{array}$ & $\begin{array}{l}\text { Equivalent to high (5) score for } \\
\text { forebay sections of reservoirs in } \\
\text { Ridge and Valley ecoregion of } \\
\text { Tennessee River Valleyc, i.e., }>3 \\
\text { species }\end{array}$ & $\begin{array}{l}\text { Equivalent to medium (3) score for } \\
\text { forebay sections of reservoirs in } \\
\text { Ridge and Valley ecoregion of } \\
\text { Tennessee River Valley, i.e., 2-3 } \\
\text { species }\end{array}$ & $\begin{array}{l}\text { Equivalent to low (1) score for } \\
\text { forebay sections of reservoirs in } \\
\text { Ridge and Valley ecoregion of } \\
\text { Tennessee River Valley, i.e., }<2 \\
\text { species in Reservoir Fish } \\
\text { Assemblage Index }\end{array}$ \\
\hline
\end{tabular}

Taxa richness - waterbirds $^{\mathrm{d}} \quad>75 \%$ (i.e., $>11$ species) of the 15 waterbird species observed at ETTP during 10 months of waterbird surveys in 2004

Number of sensitive fish species

Ambient dissolved oxygen concentration- fish $^{\mathrm{e}}$

Ambient dissolved oxygen concentration - invertebrates

Presence of shallow areas for amphibian reproduction

Presence of waterbird rookery

Number of nonnative or invasive species - fish $^{\mathrm{f}}$

Presence of nonnative or invasive species - shellfish

Complexity of habitat structure

\begin{abstract}
Abundance of rare speciesfish $^{\mathrm{g}}$
\end{abstract}

Presence of rare species-bats

Presence of rare communitywetlands

Presence of movement corridor-fish

$>1$ sensitive species present (brook silverside, logperch, spotted sucker, greenside darter, snubnose darter)

30-day mean above $5.5 \mathrm{mg} / \mathrm{L}$ and minimum measurement above $3.0 \mathrm{mg} / \mathrm{L}$, indicating no impairment of production of warmwater fish (USEPA, 1986)

30-day mean above $5 \mathrm{mg} / \mathrm{L}$, indicating no impairment of production of invertebrates (USEPA, 1986)

Extensive shallow areas present

\section{Rookery present}

Non-North American native species absent (common carp, grass carp, goldfish)

Nonnative species absent

$>8$ of the following ecosystem structural elements: woody debris, root wads, undercut banks, boulders, cobble, gravel, sand, vegetation, shallows $(<0.3 \mathrm{~m}$ depth), deep areas ( $>3 \mathrm{~m}$ depth), overhanging vegetation

More than one individual (flame chub, spotfin chub, Tennessee dace)

T\&E bats present

Presence of floodplain pool, boggy forested wetlands, or streamhead seepage swamps (rare communities according to TNC, 1995)

Easily accessible to upstream and downstream sources of fish for aquatic vegetation, emergent
Between 25\% and 75\% (i.e., 4-11 species) of the 15 bird species observed at ETTP during 10 months of waterbird surveys in 2004

1 sensitive species present

$<25 \%$ (i.e., $<4$ ) of the 15 waterbird species observed at ETTP during 10 months of waterbird surveys in 2004

No sensitive fish species present

30-day mean between $3.5 \mathrm{mg} / \mathrm{L}$, indicating severe impairment of production of warmwater fish, and $5.5 \mathrm{mg} / \mathrm{L}$, indicating slight impairment of production of warmwater fish (USEPA, 1986)

30-day mean between 4 and $5 \mathrm{mg} / \mathrm{L}$, indicating some impairment of production of invertebrates (USEPA, 1986)

Few shallow areas present

30-day mean at or below $3.5 \mathrm{mg} / \mathrm{L}$, indicating severe impairment of warmwater fish (USEPA, 1986)

30-day mean below $4 \mathrm{mg} / \mathrm{L}$, indicating acute mortality (USEPA, 1986)

Shallow areas absent

Rookery absent

One non-North American native species present

Nonnative species present

$>1$ non-North American native species present

Invasive species present (e.g., Asiatic clam, Corbicula fluminea; zebra mussel, Dreissena polymorpha)

4-8 types of ecosystem structural elements

$<4$ types of ecosystem structural elements

No individuals

Rare bats absent

Absence of floodplain pool, boggy forested wetlands, or streamhead seepage swamps (rare communities according to TNC, 1995) 
Table 3 (continued)

\begin{tabular}{|c|c|c|c|}
\hline Metrics & High habitat value & Medium habitat value & Low habitat value \\
\hline & $\begin{array}{l}\text { colonization; wide range of taxa } \\
\text { that include species that are not } \\
\text { strong swimmers indicates that } \\
\text { weirs are at least easily accessible at } \\
\text { high flows and high water levels }\end{array}$ & $\begin{array}{l}\text { Easily accessible to upstream or } \\
\text { downstream sources of fish for } \\
\text { colonization }\end{array}$ & $\begin{array}{l}\text { Not easily accessible to upstream } \\
\text { and downstream sources of fish for } \\
\text { colonization }\end{array}$ \\
\hline $\begin{array}{l}\text { Presence of movement } \\
\text { corridor-avian piscivores }\end{array}$ & $\begin{array}{l}\text { Additional water bodies within } \\
\text { territory of herons, kingfishers, } \\
\text { osprey }\end{array}$ & Not applicable & $\begin{array}{l}\text { No additional water bodies within } \\
\text { territory of herons, kingfishers, } \\
\text { osprey, etc. }\end{array}$ \\
\hline $\begin{array}{l}\text { Area of water coverage relative } \\
\text { to Southern Appalachian } \\
\text { regional average }\end{array}$ & $\begin{array}{l}>2 \% \text { of local area covered by } \\
\text { water bodies }\end{array}$ & $\begin{array}{l}1-2 \% \text { of local area covered by } \\
\text { water bodies }\end{array}$ & $\begin{array}{l}<1 \% \text { of local area covered by } \\
\text { water bodies }\end{array}$ \\
\hline $\begin{array}{l}\text { Riparian wetland coverage } e^{i} \\
\text { relative to Southern } \\
\text { Appalachian average }\end{array}$ & $\begin{array}{l}>2 \% \text { of pond riparian zone is } \\
\text { wetlands }\end{array}$ & $\begin{array}{l}0.5-2 \% \text { of pond riparian zone is } \\
\text { wetlands }\end{array}$ & $\begin{array}{l}<0.5 \% \text { of pond riparian zone is } \\
\text { wetlands }\end{array}$ \\
\hline $\begin{array}{l}\text { Forested riparian coverage }{ }^{\mathrm{j}} \text {, } \\
\text { relative to Southern } \\
\text { Appalachian coverage }\end{array}$ & $\begin{array}{l}>80 \% \text { of pond riparian zone is } \\
\text { forested }\end{array}$ & $\begin{array}{l}60-80 \% \text { of pond riparian zone is } \\
\text { forested }\end{array}$ & $\begin{array}{l}<60 \% \text { of pond riparian zone is } \\
\text { forested }\end{array}$ \\
\hline $\begin{array}{l}\text { Forested riparian coverage }{ }^{\mathrm{k}} \text {, } \\
\text { relative to Ridge and Valley } \\
\text { regional coverage }\end{array}$ & $\begin{array}{l}>40 \% \text { of pond riparian zone is } \\
\text { forested }\end{array}$ & $\begin{array}{l}30-40 \% \text { of pond riparian zone is } \\
\text { forested }\end{array}$ & $\begin{array}{l}<30 \% \text { of pond riparian zone is } \\
\text { forested }\end{array}$ \\
\hline Adjacent amphibian habitat & $\begin{array}{l}\text { Amphibian foraging, refuge or } \\
\text { overwintering habitat zone }{ }^{1} \text { to a } \\
\text { distance of at least } 159-290 \mathrm{~m} \\
\text { (Semlitsch and Bodie, 2003) } \\
\text { surrounding }>75 \% \text { of wetland area } \\
\text { at site }\end{array}$ & $\begin{array}{l}\text { Amphibian foraging, refuge or } \\
\text { overwintering habitat zone to a } \\
\text { distance of at least } 159-290 \mathrm{~m} \\
\text { (Semlitsch and Bodie, 2003) } \\
\text { surrounding } 25-75 \% \text { of wetland } \\
\text { areas at site or to a distance of at } \\
\text { least } 80 \mathrm{~m} \text { surrounding at least } 75 \% \\
\text { of wetland areas at site }\end{array}$ & $\begin{array}{l}\text { Amphibian foraging, refuge or } \\
\text { overwintering habitat zone to a } \\
\text { distance of at least } 159-290 \mathrm{~m} \\
\text { (Semlitsch and Bodie, 2003) } \\
\text { surrounding }<25 \% \text { of wetland area } \\
\text { at site or to a distance of less than } \\
80 \mathrm{~m} \text { surrounding }<50 \% \text { of } \\
\text { wetland area at site }\end{array}$ \\
\hline Adjacent reptile habitat & $\begin{array}{l}\text { Reptile upland habitat zone for } \\
\text { nesting, aestivating, feeding, } \\
\text { hibernating, and basking to a } \\
\text { distance of at least } 127-289 \mathrm{~m} \\
\text { (Semlitsch and Bodie, 2003) } \\
\text { surrounding }>75 \% \text { of wetland area } \\
\text { at site }\end{array}$ & $\begin{array}{l}\text { Reptile upland habitat zone for } \\
\text { nesting, aestivating, feeding, } \\
\text { hibernating, and basking to a } \\
\text { distance of at least } 127-289 \mathrm{~m} \\
\text { (Semlitsch and Bodie, 2003) } \\
\text { surrounding } 25-75 \% \text { of wetland } \\
\text { areas at site or to a distance of at } \\
\text { least } 80 \mathrm{~m} \text { surrounding at least } 75 \% \\
\text { of wetland areas at site }\end{array}$ & $\begin{array}{l}\text { Reptile upland habitat zone for } \\
\text { nesting, aestivating, feeding, } \\
\text { hibernating, and basking to a } \\
\text { distance of at least } 127-289 \mathrm{~m} \\
\text { (Semlitsch and Bodie, 2003) } \\
\text { surrounding }<25 \% \text { of wetland area } \\
\text { at site or to a distance of less than } \\
80 \mathrm{~m} \text { surrounding }<50 \% \text { of } \\
\text { wetland area at site }\end{array}$ \\
\hline
\end{tabular}

ETTP: East Tennessee Technology Park;

NA: not applicable;

T\&E: threatened and endangered.

${ }^{a}$ Based on distributional and habitat use information in Etnier and Starnes (1993) specific to ponds in the Clinch River drainage within the Ridge and Valley Province, TN.

${ }^{\mathrm{b}}$ Indicator of high quality littoral zone.

${ }^{c}$ From Reservoir Fish Assemblage Index (McDonough and Hickman, 1999). Average reservoir size may be larger than the ponds in this study.

${ }^{\mathrm{d}}$ We have no regional reference, ecoregional, or Appalachian data for waterbirds. Also, waterbird surveys are less quantitative than other types of surveys because different ecosystem types have different visibility.

${ }^{\mathrm{e}}$ It is assumed that dissolved oxygen concentrations are measures of diversity as well as abundance.

${ }^{\mathrm{f}}$ There is quite a bit of uncertainty regarding where some North American natives (e.g., fathead minnow and redbreast sunfish) formerly occurred and where they were introduced at the regional scale. Therefore, we focus on nonnative species from Asia in this analysis.

${ }^{\mathrm{g}} \mathrm{T} \& \mathrm{E}$ species have rare and spotty distributions in region, and we believe that abundance of these individuals is a better measure of rarity than number of rare species. Sampling effort is an important determinant of the number of rare individuals identified. For the subject and reference streams in Efroymson et al. (in press), sampling is rigorous and has been undertaken for two decades. The valuation metric is a simple, relative one, based on experience.

${ }^{\mathrm{h}}$ Flooded river and lake surface is about $1.5 \%$ of the total Southern Appalachian Assessment area (SAMAB, 1996a).

${ }^{\mathrm{i}}$ Riparian zone wetlands average $0.7 \%$ of total riparian area for Southern Appalachian Assessment area (SAMAB, 1996a). Because average is based on 30-m buffer, our range has higher midpoint, allowing for smaller wetlands at lower resolution.

${ }^{\mathrm{j}} 69.9 \%$ of the Southern Appalachian riparian zone is forested (SAMAB, 1996a).

${ }^{\mathrm{k}}$ Less than $40 \%$ of the Ridge and Valley riparian zone is forested (SAMAB, 1996a).

${ }^{1}$ Consisting of leaf litter, coarse woody debris, boulders, small mammal burrows, cracks in rocks, spring seeps and rocky pools. 
Table 4

Habitat value metrics and scoring criteria for terrestrial land areas

\begin{tabular}{|c|c|c|c|}
\hline Metric & High habitat value & Medium habitat value & Low habitat value \\
\hline Major vegetation cover type ${ }^{a}$ & $\begin{array}{l}\text { Forest and native herbaceous cover } \\
\text { such as barrens and marshes }\end{array}$ & $\begin{array}{l}\text { Managed or recently disturbed } \\
\text { systems such as mowed grass, }\end{array}$ & $\begin{array}{l}\text { Frequently mowed areas, industrial } \\
\text { infrastructure, paved areas, gravel }\end{array}$ \\
\hline
\end{tabular}
roller-chopped areas, herbicidetreated areas, shrub/scrub cover and pine plantations

Percent impervious surface or bare ground

Taxa richness, breeding birds, forest species

Taxa richness, breeding birds, edge or early successional species

Habitat suitability relationship - reptiles

Presence of nonnative or invasive species - plants

Complexity of vertical habitat structure

Length of edge between patches

Presence of rare species - plants Age of vegetation ${ }^{b}$

Presence of special wildlife breeding areas

Presence of rare species-birds

Presence of rare terrestrial vegetation community

Designation of land as a preliminary conservation site on the ORR based on Biological Significance Rankings of the Nature Conservancy

Part of ecological corridor linking deciduous forests from Cumberland Plateau to Great Smoky Mountains
Less than $10 \%$

$>75 \%$ of highest bird richness observed in a single day at East Fork Ridge Road/McNew Hollow Road area of the ORR (21), i.e., $>15$ species

$>75 \%$ of highest bird richness observed in a single day at Freels Bend area of the ORR (25), i.e., $>18$ species

Unmowed grass for most turtles and lizards; all successional stages for most snakes (Wilson, 1995; Trani, 2002)

Native species present over greater than $90 \%$ of canopy, shrub, and herbaceous layer of each plant community

Having at least four of five characteristics: $>50 \%$ canopy cover; $>50 \%$ shrub cover; $>50 \%$ ground vegetation cover above $0.5 \mathrm{~m}$; significant litter, fallen logs and/or rocks, and high moisture (modified from Newsome and Catling, 1979)

Extensive edge between at least three patches of vegetation

$\mathrm{T} \& \mathrm{E}$ or other rare species present Mid-successional (41-80 years, value for mixed mesophytic hardwood forests, SAMAB, 1996b)

Special breeding areas present (e.g., nests, male display areas)

T\&E birds present

Presence of one of seven rare vegetation communities on the Oak Ridge Reservation (TNC, 1995) ${ }^{\mathrm{c}}$ Biological Significance Ranking of BSR 1 (outstanding significance), BSR 2 (very high significance), or BSR 3 (high significance) based on clusters of T\&E species, significant communities, or other important landscape features (TNC, 1995)

Presence of deciduous forest or other vegetation cover type in primary ecological corridor connecting forest patches of forestloving species (W. Hargrove and F. Hoffman, unpublished data)
$10-50 \%$

Between $25 \%$ and $75 \%$ of highest bird richness observed in a single day at East Fork Ridge Road/ McNew Hollow Road area of the ORR (21), i.e., 6-15 species

Between $25 \%$ and $75 \%$ of highest bird richness observed in a single day at Freels Bend area of the ORR (25), i.e., 7-18 species

Sapling, poletimber, and sawtimber successional stages for most turtles and lizards (Wilson, 1995; Trani, 2002). Mowed grass has medium suitability for reptiles

Native species dominant $(>50 \%)$ in majority of plant communities at site

Having two or three characteristics: $>50 \%$ canopy cover; $>50 \%$ shrub cover; $>50 \%$ ground vegetation cover above $0.5 \mathrm{~m}$; significant litter, fallen logs and/or rocks, and high moisture (modified from Newsome and Catling, 1979)

Two habitat patches with an edge between them

T\&E species absent

Saplings and poletimber (11-40 years, value for mixed mesophytic hardwood forests, SAMAB, 1996b)

Special breeding areas absent

Presence of regionally rare birds

Absence of the seven rare vegetation communities listed in TNC (1995)

Biological significance ranking of BSR 4 (Moderate significance) or BSR 5 (of general biodiversity interest) (TNC, 1995) areas

Over $50 \%$

$<25 \%$ of highest bird richness observed in a single day at East Fork Ridge Road/McNew Hollow Road area of the ORR (21), i.e., $<6$ species

$<25 \%$ of highest bird richness observed in a single day at Freels Bend area of the ORR (25), i.e., $<7$ species

Industrial infrastructure, paved areas, gravel areas with little or no associated vegetation

Invasive or nonnative species dominant $(>50 \%)$ in the majority of the communities found at site

Having fewer than two characteristics: $>50 \%$ canopy cover; $>50 \%$ shrub cover; $>50 \%$ ground vegetation cover above $0.5 \mathrm{~m}$; significant litter, fallen logs and/or rocks, and high moisture (modified from Newsome and Catling, 1979)

No edge between vegetation associations

Grass, shrubs and seedlings $(0-10$ years, value for mixed mesophytic hardwood forests, SAMAB, 1996b)

Rare birds absent

Surveyed but not designated as BSR 1-5

Absence of deciduous forest or other vegetation cover type in primary ecological corridor connecting forest patches of forestloving species (W. Hargrove and F. Hoffman, unpublished data) 
Table 4 (continued)

\begin{tabular}{llll}
\hline Metric & High habitat value & Medium habitat value & Low habitat value \\
\hline Adjacency to conservation area & $\begin{array}{l}\text { Adjacent to or part of Black Oak } \\
\text { Ridge Conservation Easement (see } \\
\text { Efroymson et al., in press, Fig. 3, } \\
\text { this volume) }\end{array}$ & $\begin{array}{l}\text { Adjacent to conservation easement, } \\
\text { but land use prevents area from } \\
\text { merging with conserved habitat } \\
\text { patch (i.e., becoming deciduous } \\
\text { forest) }\end{array}$ & $\begin{array}{l}\text { Not adjacent to or part of Black } \\
\text { Oak Ridge Conservation Easement }\end{array}$ \\
& & & \\
\hline
\end{tabular}

BSR: biological significance ranking; NA: not applicable; ORR: Oak Ridge Reservation; T\&E: threatened and endangered.

${ }^{\mathrm{a}}$ More direct measurements of plant species richness are not available at sites of interest.

${ }^{\mathrm{b}}$ It is assumed that older vegetation is rarer, and these vegetation associations would take longer to recover/replicate. One type of estimate of the minimum time to recovery could be provided by the average age of the lost vegetation (Vasek et al., 1975).

${ }^{\mathrm{c}}$ Northern white-cedar woodland, oak-hickory-ash limestone woodland, limestone cliff, limestone sinkhole, limestone barren (annual grass-dominated), limestone barren (perennial grass-dominated), ridge and valley calcareous mixed mesophytic forest.

Habitat value metrics for terrestrial vegetation rely on regional studies of natural land cover. Deciduous forests dominated by white oak (Quercus alba) and hickory (Carya) species are dominant in upland terrestrial areas within this region; however, glades and barrens also occur (Martin, 1989). Return intervals for disturbance events in these forest systems range from 50 to 200 years (Runkle, 1985), imparting a high habitat value for those forests of mid-successional age or greater. Users of these methods must consider whether the regional context of a particular metric matches their needs and interests.

While space and time are components in any habitat valuation metric within any ecological system, spatiotemporal scales also indicate the dominant environmental processes and biotic responses at a particular scale (Delcourt, et al. 1983). These scales are important to recognize when attempting to manage an ecosystem within its natural variability. Accordingly, managers should choose time and space scales that reflect appropriate underlying processes when determining the value of a specific site (see Landres et al., 1999 for further discussion). As an example, if adjacent land cover is considered valuable for a site, then valuation should rely on metrics at local scales that reflect processes which vary between land cover types. Conversely, when considering the presence of a certain species or vegetation type at a regional scale, then larger scale processes such as climate change will be more important to consider in valuing habitat.

\section{Discussion of management implications}

Information about habitat value may be used to inform remedial decisions in various ways. Low habitat value can be used to support a decision not to remediate soils, waters, or sediments that have high ecotoxicity. Kapustka et al. (2001) suggest that contaminated sites with poor quality habitat are more credible candidates for slow, inexpensive bioremediation. Conversely, low habitat value, if attributed specifically to toxicity in the ecological risk assessment, may justify a decision to remediate, because remediation will improve habitat value and species abundance and reproduction. Similarly, high habitat value can justify cleanup or restoration on ecological grounds, or it can be used to argue that remediation is not needed. A finding that habitat value will improve for many taxa under a noaction alternative may be used to justify the selection of this alternative. Habitat restoration or enhancement may be used to attract animals away from contaminated sites (Kapustka et al., 2001). Some aspects of promoting high habitat value may in conflict with minimizing contaminant exposure. For example, high freshwater connectivity is associated with high species richness, but this connectivity promotes contaminant migration. High value habitat in a contaminated area may result in higher levels of exposure as organisms spend disproportionately more time in better quality habitat. Future use of the metrics in this study will require continued and perhaps policy-driven (Burger et al., 2004) environmental monitoring.

\section{Conclusions}

We developed an approach for including habitat valuation in the contaminant remediation decision-making process. The method involves the use of three broad categories of metrics: site use by groups of organisms, site rarity, and use value added from spatial context. Examples of use value metrics are taxa richness, a direct measure of the number of species that inhabit an area, complexity of habitat structure, an indirect measure of the potential number of species that may use the area, and land use designation, a measure of the length of time that the area will be available for use. Measures of rarity are the presence of rare species, communities, or landscape features. The presence of habitat corridors is the primary example of a metric for habitat use value added from spatial context. The operationalization of this approach for groups of organisms in contaminated streams, ponds, and terrestrial ecosystems involves the selection of more specific metrics and cutoffs for high, medium, and low habitat value that are dependent on existing data. A companion paper describes the implementation of these habitat valuation metrics and scoring criteria in the remedial investigation for ETTP (Efroymson et al., in press). 


\section{Acknowledgments}

Bechtel Jacobs Company LLC (BJC) provided the funding for this project. We would like to thank Julie Pfeffer for serving as the project manager, Sharon Thoms of EPA and Steve Alexander of USFWS for providing guidance on metric selection and pointing us toward existing habitat evaluation methodologies, Sherri Cotter of ORNL and Art Day of BJC for providing maps, Pat Parr for providing information about rare communities and previous habitat and rare species studies at the ORR, Virginia Dale of ORNL for providing guidance on metric selection and terminology, Robert T. Bay of USFWS for discussions of valuation metrics during the site visit, Carl Froede of EPA and Thomas Gebhart of TDEC for early discussions of the scope of this study, Chuck Maurice and Mary White of EPA Region 5 for information about CrEAM, and Holly Mehl for information about EPA Region 7's critical ecosystem tool.

\section{References}

Allen II, P.D., Chapman, D.J., Lane, D., 2005. Scaling environmental restoration to offset injury using Habitat Equivalency Analysis. In: Bruins, R.J.F., Heberling, M.T. (Eds.), Economics and Ecological Risk Assessment: applications to Watershed Management. CRC Press, Boca Raton, FL, pp. 165-184.

Andren, H., 1994. Effects of habitat fragmentation on birds and mammals in landscapes with different proportions of suitable habitat: a review. Oikos 71, 355-366.

Barbour, M.T., Gerritsen, J., Snyder, B.D., Stribling, J.B., 1999. Rapid Bioassessment Protocols for Use in Streams and Wadeable Rivers: Periphyton, Benthic Macroinvertebrates and Fish, second ed. EPA 841-B-99-002. US Environmental Protection Agency, Office of Water, Washington, DC.

Benton, T.G., Vickery, J.A., Wilson, J.D., 2003. Farmland biodiversity: is habitat heterogeneity the key? Trends in Ecology \& Evolution 18, 182-188.

Bond, A.B., Stephens Jr., J.S., Pondella II, D.J., Allen, M.J., Helvey, M., 1999. A method for estimating marine habitat values based on fish guilds, with comparisons between sites in the southern California Bight. Bulletin of Marine Sciences 64, 219-242.

Borenstein, S., 2005. America's vanilla landscapes mean more animals but fewer species. Knight Ridder Newspapers. Community Forest Resource Center. 〈http://www.forestrycenter.org/News/news. cfm?News_ID $=980>$.

Bruins, R.J.F., Heberling, M.T., 2005. Using multimetric indices to define the integrity of stream biological assemblages and instream habitat. In: Bruins, R.J.F., Heberling, M.T. (Eds.), Economics and Ecological Risk Assessment: Applications to Watershed Management. CRC Press, Boca Raton, FL, pp. 137-142.

Burger, J., Carletta, M.A., Lowrie, K., Miller, K.T., Greenburg, M., 2004. Assessing ecological resources for remediation and future land uses on contaminated lands. Environmental Management 34, 1-10.

Carlsen, T.M., Cody, J.D., Kercher, J.R., 2004. The spatial extent of contaminants and the landscape scale: an analysis of the wildlife, conservation biology, and population modeling literature. Environmental Toxicology and Chemistry 23, 798-811.

Crowder, L.B., Cooper, W.E., 1982. Habitat structural complexity and the interaction between bluegills and their prey. Ecology 63, 1802-1813.

Dahl, T.E., 2000. Status and trends of Wetlands in the Conterminous United States 1986 to 1997. US Department of the Interior, Fish and Wildlife Service, Washington, DC. 〈http://wetlands.fws.gov/ statusandtrends.htm $>$.
Daily, G.C. (Ed.), 1997. Nature's Services. Societal Dependence on Natural Ecosystems. Island Press, Washington, DC.

Delcourt, H.R., Delcourt, P.A., Webb, T., 1983. Dynamic plant ecology: the spectrum of vegetational change in space and time. Quaternary Science Reviews 1, 153-175.

Diaz, R.J., Solan, M., Valente, R.M., 2004. A review of approaches for classifying benthic habitats and evaluating habitat quality. Journal of Environmental Management 73, 165-181.

Doherty, M., Kearns, A., Barnett, G., Sarre, A., Hochuli, D., Gibb, H., Dickman, C., 2000. The interaction between habitat conditions, ecosystem processes, and terrestrial biodiversity - a review. Australia: State of the Environment, Second Technical Paper Series (Biodiversity), Department of the Environment and Heritage, Canberra, Australia.

Downes, B.J., Lake, P.S., Schreiber, E.S.G., Glaister, A., 1998. Habitat structure and regulation of local species diversity in a stony, upland stream. Ecological Monographs 68, 237-257.

Dunford, R.W., Ginn, T.C., Desvousges, W.H., 2004. The use of habitat equivalency analysis in natural resource damage assessments. Ecological Economics 48, 49-70.

Efroymson, R.A., Nicolette, J.P., Suter II., G.W., 2004. A framework for Net Environmental Benefit Analysis for remediation or restoration of contaminated sites. Environmental Management 34, 315-331.

Efroymson, R.A., Peterson, M.J., Giffen, N.R., Ryon, M.G., Smith, J.G., Roy, W.K., Welsh, C.J., Druckenbrod, D.L., Hargrove, W.W., Quarles, H.D., 2005. Investigating Habitat Value in Support of Remedial Decisions: A Case Study of Six Sites at the East Tennessee Technology Park. BJC/OR-2268. Bechtel Jacobs Company, Oak Ridge, TN.

Efroymson, R.A., Peterson, M.J., Giffen, N.R., Ryon, M.G., Smith, J.G., Hargrove, W.W., Roy, W.K., Welsh, C.J., Druckenbrod, D.L., Quarles, H.D., (in press). Investigating habitat value to inform contaminant remediation options: Case study. Journal of Environmental Management, doi:10.1016/j.jenvman.2007.07.024.

Etnier, D.A., Starnes, W.C., 1993. The Fishes of Tennessee. The University of Tennessee Press, Knoxville, TN.

Gerritsen, J., 1995. Additive biological indices for resource management. Journal of North American Benthological Society 14, 451-457.

Hargrove, W.W., Hoffman, F.M., Efroymson, R.A., 2005. A practical map-analysis tool for detecting dispersal corridors. Landscape Ecology 20, 361-373.

Hays, R.L., Summers, C., Seitz, W., 1981. Estimating Wildlife Habitat Variables, FWS/OBS-81/47. USDI Fish and Wildlife Service, Washington, DC.

Hooper, D.U., Chapin III, F.S., Ewel, J.J., Hector, A., Inchausti, P., Lavorel, S., Lawton, J.H., Lodge, D.M., Loreau, M., Naeem, S., Schmid, B., Setala, H., Symstad, A.J., Vandermeer, J., Wardle, D.A., 2005. Effects of biodiversity on ecosystem functioning: a consensus of current knowledge. Ecological Monographs 75, 3-35.

Johnson, M.P., Frost, N.J., Mosley, M.W.J., Roberts, M.F., Hawkins, S.J., 2003. The area-independent effects of habitat complexity on biodiversity vary between regions. Ecology Letters 6, 126-132.

Kapustka, L.A., 2003. Rationale for use of wildlife habitat characterization to improve relevance of ecological risk assessments. Human and Ecological Risk Assessment 9, 1425-1430.

Kapustka, L.A., Galbraith, H., Luxon, M., Yokum, J., 2001. Using landscape ecology to focus ecological risk assessment and guide risk management decision-making. Toxicology Industrial and Health 17, 236-246.

Kapustka, L.A., Galbraith, H., Luxon, M., Yokum, J., Adams, W.J., 2004. Predicting biodiversity potential using a modified layers of habitat model. In: Kapustka, L., Galbraith, H., Luxon, M., Biddinger, G.R. (Eds.), Landscape Ecology and Wildlife Habitat Evaluation: critical Information for Ecological Risk Assessment, Land-Use Management Activities, and Biodiversity Enhancement Practices, ASTM STP 1458. ASTM International, West Conshohocken, PA, pp. 107-128.

Karr, J.R., 1981. Assessment of biotic integrity using fish communities. Fisheries 6 (6), 21-27.

Karr, J.R., Fausch, K.D., Angermeier, P.L., Yant, P.R., Schlosser, I.J., 1986. Assessing biological integrity in running waters: a method and its 
rationale. Special publication 5. Illinois Natural History Survey, Champaign, IL. as cited in Barbour, M.T., Gerritsen, J., Snyder, B.D., Stribling, J.B., 1999. Rapid Bioassessment Protocols for Use in Streams and Wadeable Rivers: Periphyton, Benthic Macroinvertebrates and Fish, second ed. EPA 841-B-99-002. US Environmental Protection Agency, Office of Water, Washington, DC.

King, D.M., Wainger, L.A., Bartoldus, C.C., Wakeley, J.S., 2000. Expanding Wetland Assessment Procedures: Linking Indices of Wetland Function with Services and Values. ERDC/EL TR-00-17. US Army Corps of Engineers Engineer Research and Development Center, Washington, D.C.

Kirk, R., Bullington, C., 2005. Tennessee Comprehensive Wildlife Conservation Strategy. International Association of Fish and Wildlife Agencies, Washington, D.C. 〈http://www.teaming.com/state_cwcs/ tennessee_cwcs.htm $>$.

Landres, P.B., Morgan, P., Swanson, F.J., 1999. Overview of the use of natural variability concepts in managing ecological systems. Ecolgical Applications 9, 1179-1188.

MacDonald, G.M., 2003. Biogeography: space, Time, and Life. Wiley, New York.

Margules, C.R., Usher, M.B., 1981. Criteria used in assessing wildlife conservation potential: a review. Biological Conservation 21, 79-109.

Martin, W.H., 1989. Forest patterns of the Great Valley of Tennessee. Journal of the Tennessee Academy of Science 64, 137-143.

Mazurek, M.J., Zielinski, W.J., 2004. Individual legacy trees influence vertebrate wildlife diversity in commercial forests. Forest Ecology and Management 193, 321-334.

McDonough, T.A., Hickman, G.D., 1999. Reservoir fish assemblage index development: a tool for assessing ecological health in Tennessee Valley Authority Impoundments. In: Simon, T.P. (Ed.), Assessing the Sustainability and Biological Integrity of Water Resources Using Fish Communities. CRC Press, Boca Raton, FL, pp. 523-540.

Miranda, L.E., Hodges, K.B., 2000. Role of aquatic vegetation coverage on hypoxia and sunfish abundance in bays of a eutrophic reservoir. Hydrobiologia 427, 51-57.

Missouri Resource Assessment Partnership, 2004. Development of critical ecosystem models for EPA Region 7. Regional Geographic Initiative (RGI) Report. Prepared for Holly Mehl and Walt Foster, Environmental Assessment Team, US Environmental Protection Agency, Kansas City, KS.

Newsome, A.E., Catling, P.C., 1979. Habitat preferences of mammals inhabiting heathlands of warm temperate coastal, montane and alpine regions of southeastern Australia. In: Specht, R.L. (Ed.), Heathlands and Related Shrublands of the World, Ecosystems of the World, vol. 9A. Elsevier Scientific Publishing Co., Amsterdam, pp. 301-316 As cited in CSIRO 1997.

Omernik, J.M., 1995. Ecoregions: a spatial framework for environmental management. In: Davis, W.S., Simon, T.P. (Eds.), Biological Assessment and Criteria: tools for Water Resource Planning and Decision Making. Lewis Publishers, Boca Raton, FL.

ORNL (Oak Ridge National Laboratory). 2002. Land and Facilities Plan. ORNL/TM-2002/1. Oak Ridge, TN.

Ostendorp, W., 2004. New approaches to integrated quality assessment of lakeshores. Limnologica 34, 160-166.

Rosenberg, D.K., Noon, B.R., Meslow, E.C., 1997. Biological corridors: form, function, and efficacy. Bioscience 47, 677-687.

Rosensteel, B.A., Awl, D.J., 1995. Wetland Surveys of Selected Areas in the K-25 Site Area of Responsibility. ORNL/TM-13033. Oak Ridge National Laboratory, Oak Ridge, TN.

Rossi, E., Kuitunen, M., 1996. Ranking of habitats for the assessment of ecological impact in land use planning. Biological Conservation 77, 227-234.

Runkle, J., 1985. Disturbance regimes in temperate forests. In: Pickett, S.T.A., White, P.S. (Eds.), The Ecology of Natural Disturbance and Patch Dynamics. Academic Press, New York, pp. 17-33.

Russell, K.N., Ikerd, H., Droege, S., 2005. A potential conservation value of unmowed powerline strips for native bees. Biological Conservation $124,133-148$.
SAMAB (Southern Appalachian Man and the Biosphere). 1996a. The Southern Appalachian Assessment Aquatics Technical Report. Report 2 of 5. US Department of Agriculture, Forest Service, Atlanta.

SAMAB (Southern Appalachian Man and the Biosphere). 1996b. The Southern Appalachian Assessment Terrestrial Technical Report. Report 5 of 5. US Department of Agriculture, Forest Service, Atlanta.

SAMAB (Southern Appalachian Man and the Biosphere). 2005. Southern Appalachian Man and the Biosphere. 〈http://www.samab.org/ $\rangle$.

Semlitsch, R.D., Bodie, J.R., 2003. Biological criteria for buffer zones around wetlands and riparian habitats for amphibians and reptiles. Conservation Biology 17, 1219-1228.

Shelton, A.D., Blocksom, K.A., 2004. A Review of Biological Assessment Tools and Biocriteria for Streams and Rivers in New England States. EPA/600/R-04/168. US Environmental Protection Agency, Cincinnati, Ohio. 〈http://epa.gov/eerd/8734.htm〉.

Short, H.L., 1984. Habitat Suitability Index Models: the Arizona Guild and Layers of Habitat Model. FWS/OBS-82/10.70. US Fish and Wildlife Service, Fort Collins, CO.

Smith, J.G., Beauchamp, J.J., Stewart, A.J., 2005. Alternative approach for establishing acceptable thresholds on macroinvertebrate community metrics. Journal of the North America Benthological Society 24, 428-440.

Stewart, S., Kahn, J.A., Wolfe, A., O’Neill, R.V., Serveiss, V.B., Bruins, R.J.F., Heberling, M.T., 2005. Valuing biodiversity in a rural valley: Clinch and Powell River watershed. In: Bruins, R.J.F., Heberling, M.T. (Eds.), Economics and Ecological Risk Assessment: Applications to Watershed Management. CRC Press, Boca Raton, FL, pp. 253-283.

Storch, D., Evans, K.L., Gaston, K.J., 2005. The species-energy-area relationship. Ecology Letters 8, 487-492.

Suter II, G.W., 1993. A critique of ecosystem health concepts and indexes. Environmental Toxicology and Chemistry 12, 1533-1539.

Tans, W., 1974. Priority ranking of biotic natural areas. The Michigan Botanist 13, 31-39.

TNC (The Nature Conservancy). 1995. The Oak Ridge Reservation, Biodiversity, and the Common Ground Process. Final Report. Prepared for Barge, Waggoner, Sumner and Cannon, Inc.

Trani, M.K., 2002. Maintaining species in the South. In: Wear, D.N., Greis, J.G. (Eds.), Southern Forest Resource Assessment. USDA Forest Service Southern Research Station, Asheville NC, pp. 113-150.

Turner, M.G., Gardner, R.H., O'Neill, R.V., 2001. Landscape Ecology in Theory and Practice. Springer, New York.

USEPA (US Environmental Protection Agency). 1986. Ambient water quality criteria for dissolved oxygen. EPA 440/5-86-003. Office of Water, Washington, DC.

USEPA (US Environmental Protection Agency). 2002. Environmental monitoring and assessment program. Washington, DC. 〈http:// www.epa.gov/emap/html/docs.html $>$.

USFWS (US Fish and Wildlife Service). 1981. Standards for the development of habitat suitability index models for use in the habitat evaluation procedures, ESM 103, US Fish and Wildlife Service, Division of Ecological Services, Washington, DC. 〈http://policy. fws.gov/ESMindex.html $>$.

Vasek, F.C., Johnson, H.B., Eslinger, D.H., 1975. Effects of pipeline construction on creosote bush scrub vegetation of the Mojave Desert. Madrono 23, 1-13.

Whicker, F.W., Hinton, T.G., MacDonnell III, M.M., Pinder, J.E., Habegger, L.J., 2004. Avoiding destructive remediation at DOE sites. Science 303, 1615-1616.

White, M.L., Maurice, C., Unpublished manuscript. CrEAM: A Method to Predict Ecological Significance at the Landscape Scale. USEPA Region 5, US Environmental Protection Agency, Chicago, IL.

Wilson, L.A., 1995. Land Manager's Guide to the Amphibians and Reptiles of the South. The Nature Conservancy, Chapel Hill, NC as cited in Trani 2002.

WRI (World Resources Institute). 2005. Millennium Ecosystem Assessment: Living Beyond our Means--Natural Assets and Human WellBeing. Washington, DC. 〈http://population.wri.org/mabeyondmeanspub-4115.html >. 